\title{
Severus (of Malaga?) and Narrative Construction
}

\author{
The Healing of Bartimaeus (VIII.119-153)
}

Discussing the in Evangelia libri XII is not a straightforward matter, and not simply because of the uncertain identity of the author, ${ }^{1}$ a certain Severus to whom a midninth-century catalogue of the library at Lorsch also attributes ten Eclogues and four books of Georgics, all now lost. Rather, what really makes it difficult to truly evaluate this work, which would be the last biblical epic of late antiquity, ${ }^{2}$ is the condition in which the text has reached us. We have a mere fragment of 717 hexameters that includes the end of the eighth book (228 verses), the 406 verses of the ninth book and the first 83 of the tenth. ${ }^{3}$ Added to the absence of a considerable part of the text is the fact that more than thirty percent of the surviving hexameters are shorn of either their beginning or final section.

Michele Cutino's valuable and articulate contribution has brought renewed attention to Severus's work, offering both a general introduction to the in Evangelia libri XII and a detailed analysis of its account of the resurrection of Lazarus (VIII.8-84). ${ }^{4}$ Taking up the baton from Cutino's analysis, so to speak, this enquiry focuses on the way Severus constructs his account of a miracle that appears in two of the Synoptic Gospels, and that is also treated by Sedulius. In doing so, it enables us to examine the relationships between the Severus text and both its biblical hypotexts and an alternative epic treatment of the same subject.

\section{The healing of Bartimaeus}

The object of this analysis is the passage that deals with the healing of the blind man Bartimaeus (VIII.119-153), ${ }^{5}$ which is described in the Gospels of Mark (10, 46-52)

\footnotetext{
1 We cannot be certain that the author of the in Evangelia libri XII is the same Bishop Severus of Malaga who died during the reign of the Emperor Maurice (582-602), and who authored an anti-Arian treatise mentioned in Isid. vir. inlustr. 43, 61.

2 On Latin biblical epics, I shall restrict myself to referring the reader to Herzog's classic text of 1975, Roberts' (1985) analysis and Deproost's overview (1997); on New Testament epics, such as that of Severus, see Green (2006).

3 Discovered by Bernhard Bischoff in the Stadtbibliothek in Trier (cf. Bischoff (1994) 9), the text was published by Otto Zwierlein in a critical edition with commentary that drew on the philological work of Berhard Bischoff, Willy Schetter, Reinhardt Herzog and Zwierlein himself. I have relied on this edition for the quotations in this essay.

4 Cutino (2016-2017).

5 See the commentary on this section in Bischoff (1994) 82-86.
} 
and Luke (18.35-43), as reproduced in the Appendix. ${ }^{6}$ Verse 119 (iamque propinquabant portis splendentis Jericho), which introduces the episode, follows the version in Luke: where Mark has Christ encounter the blind man as he is about to leave Jericho, Luke situates the episode as Christ is approaching the city. By following Luke on this occasion, Severus is able to introduce an excursus into a number of Old Testament episodes that took place in Jericho (119-136).

Iamque propinquabant portis splendentis Iericho
Quo primum fuerat meretrix, quę mente benigna
Sese seruauit propria cum gente relicta
Incolumis, murosque tuba cum perderet: intus
Bacchabant hostes, ipsam liquere, benignam
Experti, quam nulla ducis flexere minantis
Verba, sed egregio facto delusit iniquos.
Hanc disturbatam quondam praecepit Hiesus
Sic bustam remanere nec hanc repararier umquam
(Nomine nam luna Graeco quęrente uocatur)
Falsa deum credens uaria contagia lege
Extingui dixitque suis: “si fecerit ullus,
A supero capiet sceleris condigna”, fuitque;
Nam post effecta poenam condente creauit.
Ipsa manens lymfas habuit, quae peste necabant
Progenitos omnes, quas post purgauit Eliseus
Cum sale demonstrans Christi propiare ministros,
Qui lymfis mundi detergent crimina cuncta.

Severus first recalls the aid given by Rahab to the spies of Israel (vv. 120 -125, cf. Jos $2.1,3-5$ ), then the destruction of the city ordered by Joshua (vv. 126-132, cf. Jos 6.16-26), finding room to mention Origen's interpretation of the city's name (Jericho means 'moon' - v. 128 nomine nam luna Graeco quaerente uocatur). ${ }^{7}$ The excursus on Jericho ends with a note on the wickedness and the punishment of the city, and the purification of its waters by Elisha (2 reg 2.19-24), an act that prefigures the coming of Christ's ministers, who will wash away the sins the world by the waters of baptism (vv. 133-136).

The digression on Jericho is followed by the account of the miracle, which is of a similar length (VIII.137-153): ${ }^{8}$

6 In the Appendix, I reproduce the Vulgate text (ed. R Weber, Stuttgart 20075). In the course of my analysis, I highlight relevant differences between the Vulgate account and the variants of the Veteres Latinae.

7 Severus may have encountered this detail in Jerome's translation of Origen's Lexicon Nom. Hebr., PL 23, 1284 Jerico, odor eius, vel luna, Liber interpretationis Hebraicorum nominum CCSL 72. 137,2 Iericho odor eius sive luna and 157,6 Iericho luna sive odor eius.

818 verses in all, if we consider that v. 119 introduces both the excursus and the account of the miracle. 
Bartimias illic orbus sic prope sedebat, Timaei natus. sonitu perculsus et iste Pergentis populi coepit perquirere, quidnam Turba foret, dicuntque illi transire Hiesum.

Qui tum proclamans fatur: "iustissima Dauid Progenies, miserere, precor!” multique suadent, Vt taceat, crebroque magis clamabat at ille.

Flectitur his dominus uerbis gressumque repressit Atque uenire uirum iussit. mandata peragunt

Ex populo suadentque uiri gaudere, quod ipsum

Adfore praecepit. letus tunc ille reliquit

Vestimenta diu studens uenitque; rogatque:

"Quid tibi uis faciam?" "pande mea lumina” fatur.

Respondit: "pande! saluum te reddidit alma

Ipsa fides." qui mox dominum cum ple[be

Luminibus saluis sequitur super[umque

Cum populis, factum clarum quos [

In verses 137 and 138 (Bartimias illic orbus sic prope sedebat, / Timaei natus), Severus introduces the blind man, using the name given in Mc 10.46 (filius Timei Bartimeus), although rather than fïlius, which - followed by sonitu - would scan as a cretic, he uses nātus, that could also deemed a more elegant solution. The two evangelists have the blind man sitting at the side of the road, begging (sedebat ... mendicans). Severus limits himself to describing the man as sitting (sedebat), but only provides a vague idea of his location (illic...prope), and does not describe him as begging. In Mark, having heard (cum audisset) that Jesus of Nazareth was passing, ${ }^{9}$ the blind man begins to shout. Severus, taking his lead from Luke, gives him a more active role: Bartimaeus (et iste at the end of v. 138) hears the noise (v. 138 sonitu perculsus) of the advancing crowd and asks what is happening (Severus's coepit perquirere corresponds to the interrogabat in Luke). The description of the blind man's immediate reaction - introduced in v. 141 by qui tum, does not stray from that of the Gospels, although it does evince certain (small) formal variations: in place of the simple verb used in the Gospels, clamare, we find the compound proclamare (proclamans fatur); ${ }^{10}$ the combination of finite verb and participle in Lc 18.38 (et clamavit dicens) is mirrored in Severus's text in preference to the coordinate construction in Mark (coepit clamare et dicere), although the syntax is inverted, i.e. Severus's proclamans corresponds to the perfect clamavit in Luke, his fatur to the participle dicens. The use of the present indicative, meanwhile, instils the narrative with a greater urgency.

9 Transire Iesum might derive from Lc 18.37, or may have been suggested by a variant of Mc 10.47 found in a version of the Itala: Iesus esset qui transibat.

10 Proclamo, which the Veteres Latinae often use in invocations of God-in correspondence with the Greek ßoõv and compounds thereof (see ThLL X, 2, 1534,74-1535,8)-does not appear in any version of this episode (see Jülicher (1970²) 99 and Fischer (1989) 403 for Mark and Jülicher (1976²), 209 for Luke). 
The appeal to Christ, although repeated by the blind man in the accounts of Luke and Mark (Jesu, fili David, miserere mei), is only made once in Severus's text, with fili replaced by the stylistically more sophisticated progenies, which is qualified with iustissima ${ }^{11}$ an adjective that does not appear in the Gospel versions.

In v. 142, with his choice of multique, Severus follows Mc 10.48 (multi), rather than the more precise indications of Lc 18.39 (qui praeibant). He also attenuates the reaction of the crowd, which he expresses as suadent, a gentler term than the increpabant or corripiebant ${ }^{12}$ in Luke, or the comminabantur and its variants obiurgabant and increpabant in Mark. Describing the repetition of the blind man's calls, and their increasing intensity, he uses crebroque magis clamabat, which corresponds to the multo magis [or magis magisque] ${ }^{13}$ clamabat of the Gospels. At ille-which also features in Mark - is lent greater emphasis by its position in the clause, which is not uncommon in hexametric poetry. ${ }^{14}$

While the Gospels simply indicate that Jesus stops (stans), in v. 144 Severus also provides a reason: flectitur his dominus verbis gressumque repressit. In both the Gospel accounts, Christ orders that the blind man be brought to him, but only Mark reports the execution of this order, and the words of encouragement that the bystanders call to Bartimaeus (Mc 10.49). Severus follows Mark, but rather than the simple vocare of the Gospel, ${ }^{15}$ he uses the Ovidian pairing mandata peragere, ${ }^{16}$ and even specifies-albeit redundantly-that the order is carried out by members of the crowd following Jesus (v. 145f. mandata peragunt / ex populo). Luke moves directly into the dialogue between Christ and the blind man, while Mark first depicts Bartimaeus throwing off his cloak and rushing to Jesus. Here, Severus follows Mark, amplifying the drama by underlining the joy of the blind man (v. 147 letus) who had been so long striving (v. 148 diu studens). All the same, his reliquit vestimenta in vv. 147-148 is much less impactful than Mc 10.50, whether the proiecto (abiecto in the Afra) vestimento suo exiliens venit ad eum of the Vulgate and the Itala or the variants, ille vero [or qui] ut audivit proiecit vestimenta sua et exiliens venit. ${ }^{17}$

With venitque rogatque at the end of v. 148, a coordinate construction of suitably epic stamp, Severus sets the arrival of the blind man (venitque) and Christ's questioning (rogatque) in rapid succession, in doing so effecting a rather brusque change of

11 It is likely that this is an echo of Iuvenc. II.119: Progenies ueneranda Dei, rex inclite gentis. The iustissima of Severus, who describes Christ as iustissimus auctor in 9.94, with the adjective in the same metrical position, corresponds to Juvencus's veneranda.

12 Used in the Afra: cf. Jülicher $\left(1976^{2}\right) 209$.

13 A variant of Mc 10.48 that appears in the Itala-see Jülicher $\left(1970^{2}\right) 99$-and in some manuscripts mentioned by Fischer (1989) 407.

14 The digital archive Musisque deoque counts 30 other occurrences starting with Lucr. III.312.

15 Vocant, with the variants abierunt vocare and vocaverunt, both found in the Itala.

16 This construct is only found in Ov. Met. VII.502 (peragit mandata) and Trist. I.1.35 (peragas mandata).

17 See Fischer (1989) 412-413. 
grammatical subject. ${ }^{18}$ In v. 149 , a penthemimeral caesura separates Christ's question from the blind man's answer. The question takes the same form as it does in the Gospels: quid tibi vis faciam? (the word order is that of Luke). This is the only point in which Severus cites the Gospel text without modification, almost as though he wishes to lend Christ's intervention greater weight by reproducing his ipsissima verba. ${ }^{19}$

The answer-pande mea lumina-which is more sophisticated than the ut videam in both Mark and Luke, ${ }^{20}$ is echoed directly by the imperative pande, with which Christ addresses the blind man, 'ordering' him to see. The vocative used by the blind man in the Gospels (Domine in Luke, Rabboni in Mark) is sacrificed to achieve a more rapid exchange. In v. 149, Bartimaeus's request ends with fatur; the following verse begins with respondit, which introduces Christ's answer. Christ uses the same imperative, pande (scil. tua lumina) that the blind man had used in his request. Pande, here, has the same meaning as respice (or vide) ${ }^{21}$ in Luke (Mark, which Severus does not follow in this instance, has vade). In vv. 150 -151, the fides tua te salvum fecit of the Gospels is intensified as salvum te reddidit alma ipsa fides; ${ }^{22}$ ipsa is employed her to reinforce the nexus alma fides - although it was an especial favourite among Christian poets. ${ }^{23}$

The last three verses, which are shorn of their final sections, report the miracle and its consequences. Where both Gospel accounts use the coordinate constructions of et confestim vidit et sequebatur illum, Severus has luminibus salvis sequitur, with the ablative absolute reporting the miracle that has occurred, and the present indicative sequitur indicating the consequence - i.e. Bartimaeus becomes a follower of Christ. Lc 18.43-adding that the healed man followed, glorifying God, and that all the people, having witnessed what had happened, likewise praised God. Severus takes this ending (v. 153) and underlines it with the addition of factum clarum, a suitably epic iunctura that had been introduced into the Christian poetic tradition, in plural form, by Juvencus and adopted in the singular, as it is here, by both Paulinus of Périgueux and Arator. ${ }^{24}$ It is most likely that the final clause, now missing, lent the verse even greater impact. ${ }^{25}$

18 Another sudden change of subject occurs at 9. 251 suadet (scil. pater) / dicitque (scil. filius): Bischoff 199, 85 ad loc.

19 On the possible meanings of citations in biblical poetry, see Breau 2004. Ours is not the most meaningful example, but it is very unlikely that the use of the precise wording of the Gospel is a coincidence.

20 The construct appears, with this meaning, in Arator II.532 lumina pandit: see Bischoff (1994) 85 ad loc.

21 In the Afra, see Jülicher $\left(1976^{2}\right) 209$.

22 First appearance in Enn. scaen. $380 \mathrm{R}^{2}$ in pagan dactylic poetry, there are one occurrence of alma fides in Statius, and one in Silius Italicus.

23 Musisque deoque counts 3.

24 Iuvenc. II.242 Splendeat ut claris uirtutis gloria factis; Paul. Petr. I.71-72; 358 and 367; Arator II.1195. 
Regarding the stylistic and lexical choices made by Severus, there are a number of pertinent observations that we can add to the comments made thus far. The amque propinquabant portis at the start of v. 119 is found in Virgil, ${ }^{26}$ as is the quo primum of v. 120. The phrase mente benigna in v. 120 , which adapts a paring from Virgil, ${ }^{27}$ is found in this form in Christian poetry. ${ }^{28}$ Severus uses it again in VIII.200. The same adjective reappears three verses later (benignam, at the end of the verse), here again used to characterise Rahab's benevolent disposition towards the Jews. The construct egregio facto in v. 125 returns in the plural (facta egregia) in IX.372; the phrase fecerit ullus in v. 130 finds precedent-fecerit ulli-in Dracontius (laud. 2 , 585). With a supero in v. 131, Severus may be drawing on the a superis used more than once by Lucan as an hexameter opening, ${ }^{29}$ while the fuitque at the end of the same verse had been employed in the same metrical position in Ovid. Met. I.51 and Mart. X.63.7. Severus himself uses it again at IX.364. The sonitu perculsus in v. 138 is from Statius. ${ }^{30}$ In v. 139 Severus uses a hitherto unknown construction -a favourite of his-coepit perquirere. ${ }^{31} \mathrm{~V}$. 139 begins with the word pergentis; in the entirety of poetry, there are only two other es of the use of pergent ${ }^{*}$ to open an hexameter, one by Severus himself, the other by Juvencus, ${ }^{32}$ that Severus may well have recalled. Qui tum, which we encounter at the start of v. 141, appears five more times in all in dactylic poetry, two of these examples being in the Heptateuch Poem. ${ }^{33}$ In the blind man's appeal to Christ, rather than the miserere mei of the Gospels, Severus uses miserere precor, which he probably considered more elegant, and/or charged with greater pathos. ${ }^{34}$ In short, Severus is thoroughly entrenched in the Latin poetic tradition - both profane and Christian - and evinces a clear awareness of his own stylistic choices.

Bringing this analysis to a close, we can draw a number of conclusions. The digression on Jericho, which affords the author the opportunity to display his erudition on Old Testament matters, also reveals the character and limits of what Severus was

25 Two possible versions of the concluding clause have been proposed e.g. by the authors of the edition:credere fecit (cf. VIII.108 Lazar multos ... credere fecit) and moverat omnes: see Bischoff (1994), 86.

26 Cf. Aen. II.730 iamque propinquabam portis (Bischoff (1994), 82 ad loc.), but also iamque propinquabant, which appears in Aen. V.159; IX.371 and XI.621.

27 Aen. 1, 304 mentemque benignam: see Bischoff (1994) 83.

28 Musisque deoque counts 9 examples, starting with Mar. Victor. aleth. praef. 56.

29 Lucan. V.200; VIII.643; 847; IX.477. There is a previous example in Ovid. Pont. II.9.18 and a later one in $A L$ 761.50; cf. also Sil. III.485 a supera at the hexameter opening.

30 Theb. X.122 Nec sonitu nec uoce deae perculsus.

31 IX.96 coepit perquirere in the same position, and IX.106 perquirere coepit at the end of the hexameter.

32 With pergentes in Sev. VIII.53 and Iuvenc. II.436.

33 In exod. 173 and iud. 138 respectively.

34 Both constructs are found elsewhere in hexametric poetry: miserere precor appears on five other occasions, four of which use it in the same position as in our verse; miserere mei, meanwhile, counts seven examples, of which five mirror the positioning used by Severus. 
able to offer in terms of exegesis. He reports the 'moon' meaning of the name Jericho, taking pains to acknowledge Origen as his source (v. 128), but he does not allude to the deeper exegetic implications of this meaning. ${ }^{35}$ In a similar manner, he offers no typological interpretation of the figure of Rahab, who - in addition to being compared in the New Testament to the Patriarchs, both for her faith (Heb 11.31) and for her works (lac 2.25) - was treated, according to a widespread exegesis, as a type of the Church, who had been recruited from among the sinners and pagans. ${ }^{36}$ The only figural interpretation offered by Severus in this text is the treatment of the purification of the waters as a prefigurement of the sacrament of baptism. ${ }^{37}$ In short, Severus sets himself a decidedly didactic task - one that does not apply, for instance, to Juvencus - but proves reluctant to expand his exegesis of the events described.

In his retelling of the miracle, Severus remains true to his sources, although he is careful to follow whichever of the Gospel accounts affords him the richer and more detailed narrative of a particular instance. As such, he draws on Mark for the name of the blind man, which does not appear in Luke, but follows the latter both in his account of the timing of the miracle (as Christ was approaching Jericho, rather than on the way out, thereby enabling the author to introduce his excursus on the city), and in emphasising the involvement and reactions of the bystanders. In contrast to the two Gospels, he omits to mention Bartimaeus's 'profession' as a beggar, and where the blind man beseeches Jesus twice in the Gospels, he does so only once in our text, albeit - with the use of progenies and the addition of iustissima - in a more solemn manner.

The same miracle is described by Sedulius in carm. Pasch. IV.210-221: ${ }^{38}$

Cum residens caecus Timei filius illud

Propter iter, Dominum per quod cognouerat ire,

Vociferans crebro lumen clamore petisset

Nec populo prohibente tacens, accedere iussus

Ad Dominum palpante manu, uisumque recepit

Et nullo ducente redit. quam fortiter instat

215

Importuna fides! quidquid res dura negarit,

Sola frequens uotis oratio praestat honestis.

Vnanimum panem sic ille petebat amicum,

Qui foribus clausis per opaca silentia noctis

35 In Origen's interpretation, Jericho - with the meaning of its name - is figura mundi huius (In Jesu Nave 6.4 cf. ibid. 7.1 forma saeculi praesentis. We find an echo of this in Isid. in Jos. VII.1 f., PL 83, 374 (Jericho autem per interpretationem luna dicitur. luna vero mundi huius speciem tenet). The reasons for the mutability of the moon, represented by Jericho, are also explored: see Aug. in ps. 60.8, CCSL 39, 770, $28-31$ and 88.2.5, ibid. 1236, 32-37.

36 See Langlamet (1979) 1086-1079; this interpretation is offered first by Origen, In Jesu Nave VI.4: see Jaubert (1960) $44 \mathrm{f}$.

37 On this typological interpretation and its dissemination, see vv. 134-136 in Bischoff (1994) $84 \mathrm{f}$.

38 For a commentary on this episode, see van der Laan (1990) 137-143. 
Vocibus assiduis precibusque extorsit anhelis.

The account of the healing itself is much condensed in comparison not only to its counterpart in Luke, but also to the corresponding section of the Opus Paschale: it takes up less than six of the twelve verses, and is resolved in a single period. ${ }^{39}$ Sedulius highlights the contrast between the blind Bartimaeus who must grope his way to Christ, and the healed man who can make his way without aid (v. 213-215 accedere iussus / Ad Dominum palpante manu ${ }^{40}$, uisumque recepit / Et nullo ducente redit): as we find, in particular, in books III and IV, it is the wonder of the miracle that he is at pains to emphasise. ${ }^{41}$ Unlike Severus, Sedulius draws his account only from Luke, although he takes the Latin translation of the name Bartimaeus from Mc 10.46; like Severus, he neglects to say that he was a beggar. With the vociferans crebro clamore in v. 212 he condenses both the et clamavit dicens of Lc 18.38 and the ille autem multo magis clamabat of Lc 18.39 into a single image ${ }^{42}$ that denotes both the repetition and volume of the shouts. Unlike Luke, Sedulius does not allude to the assistance the blind man received in coming before Christ, ${ }^{43}$ an omission that heightens the drama of the scene.

The commentary that follows the account of the miracle, and exceeds it slightly in length, reveals Sedulius's concern not so much for the dynamics of the event as for the lesson that can be taken from it: that with importuna fides and frequens oratio anything can be obtained from God (v. $215 \mathrm{f}$.). In support of his interpretation, Sedulius (vv. 218-221) recalls an exemplum of a request fulfilled by virtue of its very importunitas, namely that made by the man who - with voces assiduae - convinces his friend to open the door in the middle of night and give him bread (Lc 11.5-8). ${ }^{44} \mathrm{Ul}$ timately, the miracle is retold in a manner that communicates this moral lesson.

Let us now consider the situation of the miracle in the context of the wider narrative. In Sedulius, the healing of Bartimaeus is preceded by the healing of the ten lepers (recounted in Lc 17.12-19), only one of which returns to thank Jesus and thus receives absolution form him (Lc 17.15-19). Here, Sedulius departs from the account in Luke (which continues with Jesus's declaration on the coming of the kingdom of God: 17.20 -37), drawing on the episode to proclaim Christ the true new Melchizedek. The healing of Bartimaeus follows immediately thereafter, without any indication for the reader of Christ's movements, nor of his location at the time of

39 On omissions in the poetry of Sedulius and his compression of the Gospel story, see van der Laan (1990) 137-138. For the relationship between prose and verse treatments, see Mori (2013).

40 Paul. Nol. carm. 18.349 and 20.406.

41 See Springer (2013) XXXVII.

42 See van der Laan (1990) 138.

43 Iussit adduci in Luke, and thus also in the Opus Paschale 267,13-14(ad Dominum venire iussus aliena manu perrexit): van der Laan (1990) 139.

44 On the dissemination of this interpretation of Lk 11.5-8, see van der Laan (1990) 140 ad loc. 
the miracle. In characteristic fashion, Sedulius cultivates the expressive impact of his narration ${ }^{45}$ without showing much concern for narrative continuity. In this sense, what we have is an example of his tendency to treat the Gospels as a source of exempla, which serve to illustrate different aspects of the way Christ effects the redemption of humanity. ${ }^{46}$

Severus, meanwhile, is preoccupied as always with ensuring the continuity of his narrative, not least when - as in this case - he shifts from one Gospel to another, and in particular when moving from John (which features heavily in the surviving sections of the poem) to the Synoptic Gospels and vice versa. ${ }^{47}$ Thus, after the resurrection of Lazarus (VIII.8-110) - for which he draws on John, with the miracle occurring at Bethany - he effects a smooth transition, using the adverb interea (VIII.111), to the Gospel of Luke, in which Jesus announces that he wishes to go to Jerusalem (before going on to foretell his impending death and resurrection: Lc 18.31-34). The encounter with the blind man and the miracle of his healing take place on this journey, as Christ is approaching the gates of Jericho (Lc 18.35). The introduction of the city provides an historic backdrop to the scene of the miracle, the details of which are evoked in a fluid narrative style that lends greater energy to the dialogue. ${ }^{48}$

\section{A comparison with another episode: the healing of the man blind from birth}

We can supplement this comparison between Severus and Sedulius with a brief analysis of the same authors' accounts of the miraculous restoration of another blind man's sight, namely the episode of the healing of the man born blind recounted in Jn 9. Severus IX.163-209 paraphrases the entire account; let us examine the part strictly related to the miracle (IX.163-180):

Post haec transibat Christus, subit[oque ministri

Adduxere orbum, qui numquam u[iderat

Ex partu lucem, mater quem prod[

165

Et dicunt: "doctor, filii peccat[a patrisve

45 Consider, in particular, the palpante manu, which he takes from (see above note 40), the per opaca silentia noctis, which derives from Valerius Flaccus (II.288), and the pairing vocibus adsiduis in v. 221, which is adapted from Virgil (Aen. IV.447 adsiduis ... vocibus). For a detailed analysis, see van der Laan (1990) 139 and 142-143. For an articulate summary of the expressive forms used by Sedulius and his baroque tastes, see Springer (2013) XXXIII.

46 On the use of miracles to emphasize the theme of salvation see Green (2006) $224 \mathrm{f}$.

47 On Severus's skill in preserving narrative continuity in the passage from one episode to another, see Cutino (2016-2017) 192-194.

48 It is Severus's 'flüssige Erzählungsweise' and 'lebhafte dialogische Gestaltung einzelner Szenen' that in Schetter's opinion 'weisen Severus im Rahmen der Bibeldichtung als einen Autor von Rang aus': Bischoff (1994) 7. 
Hunc talem nasci fecerunt?” [Christus ad ipsos

"Nullus peccauit, sed signat[

Confuso turbata modo complen[

Et reparare decet: capiet sub lu[mine lumen

Et cunctos doceat lingua reti[

Confundetque malos oculis fre[

Haec dicens lutum format, quod d[

Atque uolens multos homin[es

Hoc subitum clarumque nimis sple[ndensque

Ablutum misit Siloan monstr[

Qui multis populis cinctus[

Vndique currebant auidi $\operatorname{cog}[$ noscere

Qui postquam iussa lymphas [

Lumina detergit cernens et [

The incomplete verses notwithstanding, the way Severus constructs the episode is clear. ${ }^{49} \mathrm{He}$ is preoccupied with establishing narrative continuity in regard to the preceding text (v. 163 Post haec transibat Christus) and is faithful to his source save for a modification at the beginning of the account, which has the blind man brought to Christ by a third party (v. 164 adduxere orbum), whereas in John it is Christ himself who notices him.

The same miracle is narrated by Sedulius (IV.251-270) shortly after his account of the healing of Bartimaeus, the episodes only being separated by Christ's encounter with the Samaritan woman and the absolution of the adulteress. ${ }^{50}$

Inde means genitum cernit considere caecum,

Qui male praegnantis dilapsus uentre parentis

In lucem sine luce ruit. tunc sanguinis ille

Conditor humani mundique orientis origo,

Imperfecta diu proprii non passus haberi

Membra operis, natale lutum per claustra genarum

Illiniens hominem ueteri de semine supplet.

Nec uisum tamen ante capit, quam uoce iubentis

Accepta Domini Siloam uenisset ad undam

Et consanguinei tutus medicamine limi

Pura oculos fouisset aqua. mox ergo gemellae

Vultibus effulgent acies tandemque merentur

Ignotum spectare diem. cognoscite cuncti,

Mystica quid doceant animos miracula nostros.

Caeca sumus proles miserae de fetibus Euae,

Portantes longo natas errore tenebras.

Sed dignante Deo mortalem sumere formam

Tegminis humani, facta est ex uirgine nobis

49 The whole episode is commentated in Bischoff (1995) 120-127.

50 For a commentary on the passage from Sedulius see van Laan (1990) 165-175. 
Terra salutaris, quae fontibus abluta sacris

Clara renascentis reserat spiramina lucis.

Again, Sedulius's is the briefer retelling, with just thirteen verses to Severus's seventeen. The latter follows John's text closely, and includes the question posed to Christ as to the reason the man was born blind. Sedulius omits this exchange, seeking greater impact through a conceptual puzzle: in lucem sine luce ruit (v. 253, which he varies in op. pasch. IV.20: in lucem sine luce pervenit). Furthermore, in introducing the miracle, he takes the opportunity to remind the reader that Christ is the creator of the world, on a level with the Father (v. 254 Conditor humani mundique orientis origo and vv. 255-256 proprii ... membra operis). Having recounted the miracle, Severus continues to follow the narrative in John, describing the manner in which the Pharisees challenge the healed man (Jn 9.8-41). Sedulius, meanwhile, uses the six verses following the account to explain the meaning of the miracle (v. 263 cognoscite cuncti / Mystica quid doceant animos miracula nostros), ${ }^{51}$ in a manner that recalls the earlier explanation proffered by Prudentius: ${ }^{52}$ we are the descendents of Eve, blind from birth (v. 265), to whom a land of salvation has been created, deriving from the Virgin, thanks to Christ's incarnation, through the cleansing of baptism.

\section{Severus, Sedulius and the ineluctability of exegesis}

These two comparisons with Sedulius's treatments of the same episodes throw Severus's scarce propensity for reshaping the Gospel narrative for the purposes of theological or exegetic interpretation into sharp relief. All the same, in the course of his verse, Severus does not exempt himself entirely from providing explanations that he clearly believes will interest his readers. Alongside a number of excursus of a narrative character, ${ }^{53}$ the surviving portion of the poem contains four passages of exegisis. The first two consist in the figural interpretation of the purification of the waters of Jericho (VIII.133-136), which we have discussed already, and explanation of the

51 This very passage is singled out by Dermot Small (1986) 233 as 'an interesting example of Sedulius' method of extracting a spiritual significance from the literal events'. An interesting detail is that the typological interpretation here is applied to an episode from the New Testament in order that the healing of the blind man foreshadow the salvation of humanity from its spiritual blindness: see Dermot Small (1990) 199-200. On the use of amplificatio for exegetic purposes in Sedulius, see Roberts (1985) $165-171$.

52 For a comparison with Prud. Ap. 675-703, see van Laan (1990) 165-166. On the poetry of Prudentius as a precursor to Sedulius's epic verse, see Green (2006), 148-150.

53 In addition to the excursus, examined above, on Jericho (VIII.120 -136), there is the parallel between the Samaritan woman and Mary, who are compared with Jezabel and Eve (VIII.4-7) and an excursus on Herod the Great (IX.326-331) and his son Herod Antipas (IX.332-337). 
parable of the talents (VIII. 219-228). ${ }^{54}$ The third (IX.81-93) concludes the account of the healing of the paralysed man at Bethsaida (IX.40-92) - as recounted in Jn 5.2-18 - with an apostrophe directed at the reader:

Haec tamen exquirens poteris sentire priora

Et retinens facta specta, quid carpas ab illis:

$\star \star \star$

Sensus quinque puta peccataque turpia poenas,

Quis cuncti pariter foeda sub mente gemebant,

Depositum in medio, primus qui perditus esset.

Annorum numerum nomen retinere necati

Tractans inuenies, liuor quem prauus inique

Innocuum damnans mortis exordia fecit,

Vnum duo quinque triginta postea ponens.

Ex numero nomen poteris captare perempti,

Surgere quem superus indigna morte necatum

Praecepit uerum prisca signante figura.

Severus's exegesis makes reference to the topothesia with which the episode opens, ${ }^{55}$ and to the duration of the affliction, although the poet does not actually give the latter detail, no doubt assuming that the reader is familiar with the account in John where it is mentioned. As such, it appears that Severus is not concerned on this occasion with communicating every last detail of the episode, aligning himself here more closely with the approach of Sedulius. ${ }^{56}$ The apostrophe that introduces the allegorical interpretation exhorts the reader to grasp the deepest meaning of the Scriptures. The very urgency of this appeal, which is addressed to the reader in almost Dantean fashion, ${ }^{57}$ also leads us back to Sedulius. It is the only intervention of its kind among the surviving verses of the in evangelia libri, although we cannot exclude the (indeed highly likely) possibility that the roughly four fifths of the text that are lost to us contained others like it.

Severus's last exegetic digression is even more significant (IX.103-140). Elucidating the episode of the withered fig tree, ${ }^{58}$ which he interprets as Christ's warning to Judas (IX.124-136), Severus is at pains to put his own, original exegesis -incidenntally, the only one in any of the surviving verses - of which he claims true authorship in perspective (vv. 137-149):

54 On the nature of this reflection and the paraenesis that follows (8, 224-228), see Cutino 20162017, 198-199.

55 9, 40-44, which closely follows the description in Jn 5.2.

56 As demonstrated in Springer (1988) 28-48 and (2013) XXXV-XXXIX, Sedulius imagined a readership of initiates, who would not be 'novices to the faith by any means' (Springer (2013) XXXV). 57 The obvious reference is to Auerbach (1954).

58 IX, 103-140, on which see Cutino (2016-2017) 199-201. 
Diximus haec nostros sensus proferre uolentes; ast alios, quo quisque modo perquirere temptat, inueniet, gemmae quoniam sunt gesta superna, quae, quocumque modo tractantur, pulchra uidentur.

The poet states that he is providing his own interpretation, but that anyone who seeks to explore the meaning of the sacred text may derive another. After all, the gesta superna are precious jewels that retain their beauty however they are treated. It is a declaration that suggests that Severus considered exegesis as an obvious aspect of the text, whose practice is something that he, and his readers, would consider a matter of course.

Arator, perhaps unknown to Severus, ${ }^{59}$ had picked up the baton from Sedulius, liberating himself further from paraphrasis to develop the exegetic potential of epic poetry and put it at the service of biblical commentary. ${ }^{60}$ Severus, in contrast, adopts a much more paraphrastic approach, whereby he avoids modulating his narrative for the purposes of emphasising its exegetic dimension. He composes a poem that, in its very title, declares its author's adherence to the epic tradition and that of Virgil in particular. ${ }^{61}$ However, it is a work that, in contrast to Sedulius (who establishes a lively dialectic relationship with the Virgilian model), ${ }^{62}$ makes little space for theological or doctrinal considerations. ${ }^{63}$ All the same, writing after Sedulius - whose works he knew and clearly appreciated ${ }^{64}$ - Severus would not have been unaware of the exegetic bent his precursor had brought to the tradition of epic biblical verse (both Old and New Testament) and indeed he acknowledges it, albeit in measured fashion. His attitude, although timid in comparison to that of Sedulius, appears audacious when measured against Juvencus, a poet who shared Severus's enthusiasm for narration. Paradoxically, the very admission of few exegetic excursus, on the part of Severus, reluctant as he is to stray too far in his poem from the letter of the Gospels, helps us to appreciate how, with Sedulius, exegesis had become a distinctive trait of the Bibelepik tradition - one that would be inescapable for the poets that were to follow - and how, in this sense, the Carmen Paschale represents a watershed in the history of late-antique epic biblical poetry.

59 See Bischoff (1994) 23f. and notes 28 and 29.

60 On this aspect of Arator's writing, see Bureau-Deproost (2017), in particular XXVII-XLVII.

61 Even to the point that the surviving incipts follow those of the corresponding Virgilian books.

62 See, in particular, van Der Laan (1993) 142-143.

63 See Cutino (2016-2017) 212f.

64 See Bischoff (1994) 17-20 


\section{Appendix}

\section{Lc 18}

${ }^{35}$ Factum est autem cum adpropinquaret Hiericho cæcus quidam sedebat secus viam mendicans ${ }^{36}$ et cum audiret turbam prætereuntem interrogabat quid hoc esset $^{37}$ dixerunt autem ei quod Iesus Nazarenus transiret ${ }^{38}$ et clamavit dicens Iesu Fili David miserere mei ${ }^{39}$ et qui praeibant increpabant eum ut taceret ipse vero multo magis clamabat Fili David miserere mei ${ }^{40}$ stans autem Iesus jussit illum adduci ad se et cum adpropinquasset interrogavit illum ${ }^{41}$ dicens quid tibi vis faciam at ille dixit Domine ut videam ${ }^{42}$ et Iesus dixit illi respice fides tua te salvum fecit ${ }^{43}$ et confestim vidit et sequebatur illum magnificans Deum et omnis plebs ut vidit dedit laudem Deo

\section{Mc 10}

${ }^{46}$ Et veniunt Hierichum et proficiscente eo de Hiericho et discipulis eius et plurima multitudine filius Timei Bartimeus caecus sedebat iuxta viam mendicans ${ }^{47}$ qui cum audisset quia Iesus Nazarenus est coepit clamare et dicere Fili David Iesu miserere mei ${ }^{48}$ et comminabantur illi multi ut taceret at ille multo magis clamabat Fili David miserere mei $^{49}$ et stans Iesus praecepit illum vocari et vocant caecum dicentes ei animaequior esto surge vocat te ${ }^{\mathbf{5 0}}$ qui proiecto vestimento suo exiliens venit ad eum ${ }^{51}$ et respondens illi Iesus dixit quid vis tibi faciam caecus autem dixit ei rabboni ut videam ${ }^{52}$ Iesus autem ait illi vade fides tua te salvum fecit et confestim vidit et sequebatur eum in via

\section{Bibliography}

Auerbach (1954): Erich Auerbach, 'Dante's Addresses to the Reader', in: Romance Philology, 7, $268-78$.

Bischoff (1994): Severi episcopi <Malacitani?> in Evangelia libri XII. Das Trierer Fragment des

Bücher VIII-X. Unter Mitwirkung von R. Herzog erstmalig herausgegeben und kommentiert von

B. Bischoff und W. Schetter, bearbeitet von O. Zwierlein, München.

Bureau (2004): Bruno Bureau, 'Citer et/ou paraphraser chez quelques poètes bibliques latins: Juvencus, Sedulius, Arator', in: C. Darbo-Peschanski (ed.), La citation dans l'Antiquité: actes du colloque du PARSA Lyon, 6-8 novembre 2002, Grenoble, 199-219.

Bureau-Deproost (2017): Arator, Histoire Apostolique, Texte établi, traduit et commenté par B. Bureau et P.-A. Deproost, Paris.

Cutino (2016 - 2017): Michele Cutino, 'L'accomplissement de la paraphrase néotestamentaire en Occident: les In evangelia libri de Severus de Malaga', in: RET 6, Suppl. 4, 189-213.

Deproost (1997): Paul-Augustin Deproost, 'L'épopée biblique en langue latine. Essai de définition d'un genre littéraire', in: Latomus, 56, 14-39.

Dermot Small (1986): Caroline Dermot Small, 'Rhetoric and Exegesis in Sedulius' Carmen Paschale', in: C\&M 37, 223-244. 
Dermot Small (1990): Caroline Dermot Small, 'Typology in Sedulius' Carmen Paschale', in: Studia Patristica 18 /4, Kalamazoo-Leuven, 195-200.

Fischer (1989): Bonifatius Fischer, Die lateinischen Evangelien bis zum 10. Jahrhundert, II., Varianten zu Markus, 1989.

Green (2006): P.H. Green, Latin Epics of the New Testament. Juvencus, Sedulius, Arator, Oxford. Herzog (1975): Reinhart Herzog, Die Bibelepik der lateinischen Spätantike: Formgeschichte einer erbaulichen Gattung, Vol. 1, München.

Jaubert (1960): Annie Jaubert (ed.), Origène, Homélies sur Josué, Paris [SC 71].

Jülicher $\left(1970^{2}\right)$ : Adolf Jülicher, Itala. Das neue Testament in altlateinischer Überlieferung. II Marcus-Evangelium, Berlin.

Jülicher (1976²): Adolf Jülicher, Itala. Das neue Testament in altlateinischer Überlieferung. III Lucas-Evangelium, Berlin-New York.

Langlamet (1979): F. Langlamet, 'Rahab', Dictionnaire de la Bible, Suppl. 9, Paris, 1065-1092.

Mori (2013): Roberto Mori, Sedulio: tra prosa e poesia. L’Opus Paschale e il Carmen Paschale di Sedulio, Padova.

Roberts (1985): Michael Roberts, Biblical Epic and Rhetorical Paraphrase in Late Antiquity, Liverpool 1985

Springer (1988): Carl P. E. Springer, The Gospel as Epic in Late Antiquity. The Paschale Carmen of Sedulius, Leiden.

Springer (2013): Carl P.E. Springer, Sedulius, The Paschal Song and Hymns, translated with an introduction and notes by C. P. E. Springer, Atlanta.

van der Laan (1990): Paul Willem A. Th. van der Laan, Sedulius Carmen Paschale Boek 4, Oud-Beijerland.

van der Laan (1993): Paul Willem A. Th. van Der Laan, 'Imitation créative dans le Carmen Paschale de Sédulius', in: J. Den Boeft and A. Hilhorst (eds), Early Christian Poetry: a Collection of Essays. Leiden, Suppl. VChr 22, 135-166. 
